\title{
Wattle and Daub Experimental Workshop: Durability Testing after 14 years of Uninterrupted Use
}

\author{
Guadalupe Cuitiño, and Alfredo Esteves
}

\begin{abstract}
An important factor to analyze when studying the useful lifetime of earth constructions is the detection of any constructive pathologies that may occur; an important consideration when building a house; yet in Argentina information on building with wattle and daub is scarce. This paper describes a durability test conducted on an experimental workshop built with wattle and daub technology in 2004, in the city of Mendoza, Argentina. The building has a floor area of $33.63 \mathrm{~m} 2(5.70 \mathrm{~m} \times 5.90 \mathrm{~m})$, and houses an experimental workshop for thermal energy research and the construction of solar equipment. During the $\mathbf{1 4}$ years that the workshop has been in use, the wattle and daub walls have been exposed to various environmental forces, such as rain, wind, and earthquakes. However, its thermal behavior has remained constant over time, maintaining a difference in temperature of $5.8^{\circ} \mathrm{C}$ between the inside and outside without auxiliary heating. In general, the construction has been well-preserved and serves the purpose for which it was built, thus proving that wattle and daub constructions will remain in optimum condition for at least 14 years with minimal maintenance required to prevent surface materials from deteriorating.
\end{abstract}

Index Terms-Durability; Pathologies; Wattle and Daub.

\section{INTRODUCTION}

Examples of vernacular architecture (built with earth) are present in many geographic areas around the world as seen in Fig. 1 [1], although less commonly used in cold or very cold climates, due to the fact that in sustainable architecture achieving thermal comfort requires low thermal transmittance [2].

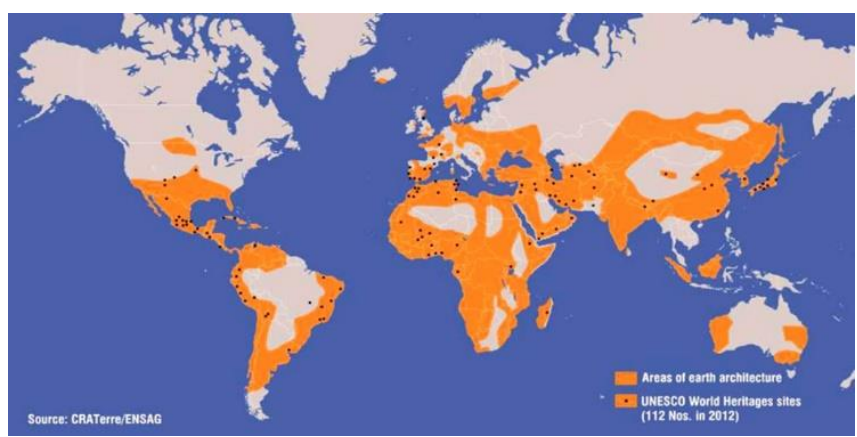

Fig. 1. World map illustrating worldwide use of earth construction [2].

Many of these buildings are ancient and are still standing despite the wear and tear caused by the passing of time. An

Published on December 21, 2018

G. Cuitiño is with the Department of Chemical Engineering - Faculty of Sciences Applied to Industry, National University of Cuyo. (e-mail: gcuitino@mendoza-conicet.gov.ar)

A. Esteves with the Institute of Environment, Habitat and Energy, Centro Científico y Tecnológico, Conicet, Mendoza, Argentina. (e-mail: aesteves@mendoza-conicet.gov.ar) example of this is the old walled city of Shibam known as "the Manhattan desert" in Yemen (Fig. 2). All houses in Shibam are made with mud bricks. It boasts 500 towers, between 5 and 9 stories high, made over 1500 years ago with local earthen materials, using mud brick, cob and rammed earth techniques [3]. Another great example is Chan Chan in Peru (Fig. 3) which is the largest preColumbian adobe city in America and the second largest in the world. Bridgwood [4] indicated that: "... the durability of an earth wall will depend on the raw materials originally employed and the degree of care with which the structure was built". In recent years an important restoration project has been undertaken, making Chin Chin's palace the best preserved example of Chimu architecture in existence. It is in fact the only archaeological site open to the public in Chan Chan, and visible almost in its entirety [5].

In Argentina, an example of the durability of earth construction is the San Bernardo Convent in the city of Salta (Fig. 4), a Catholic temple located east of the city center. This building was constructed between the XVI and XVII centuries and was declared a National Historic Landmark in 1941. Likewise, in Salta there is the ancient church of Angastaco (Fig. 5), built in 1945 by the city's residents with adobe walls, a cane roof and a brick floor [6].

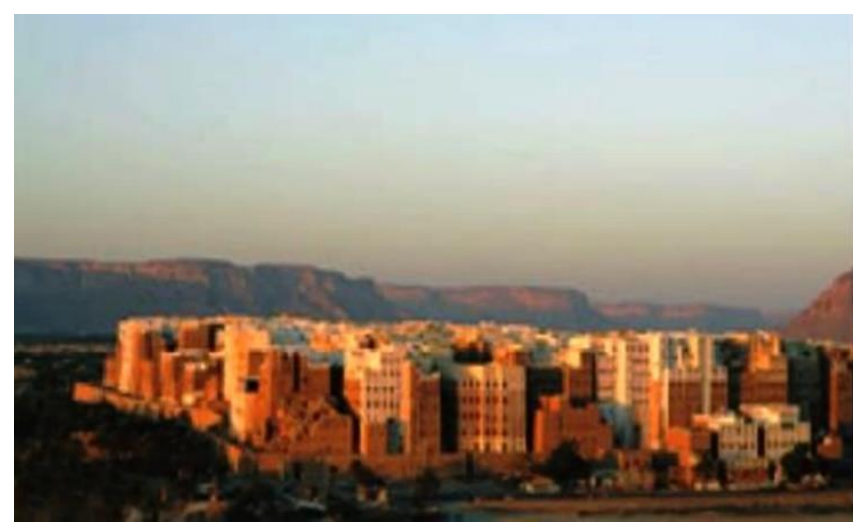

Fig. 2. The city of Shibam in Yemen [3].

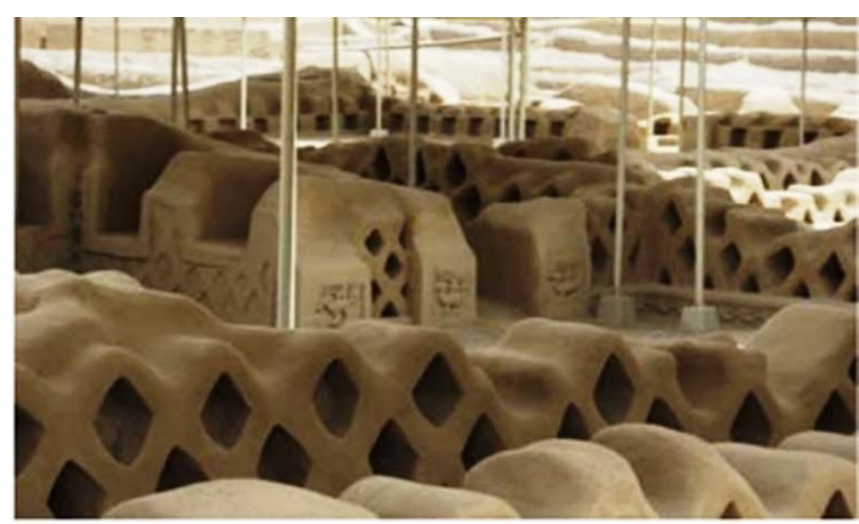

Fig. 3. The city of Chan Chan in Perú [5]. 


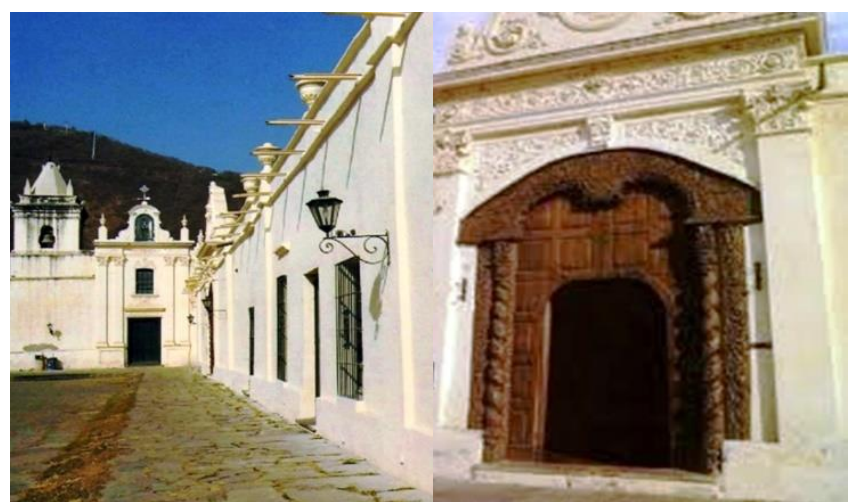

Fig. 4. The San Bernardo Convent in the city of Salta [6].

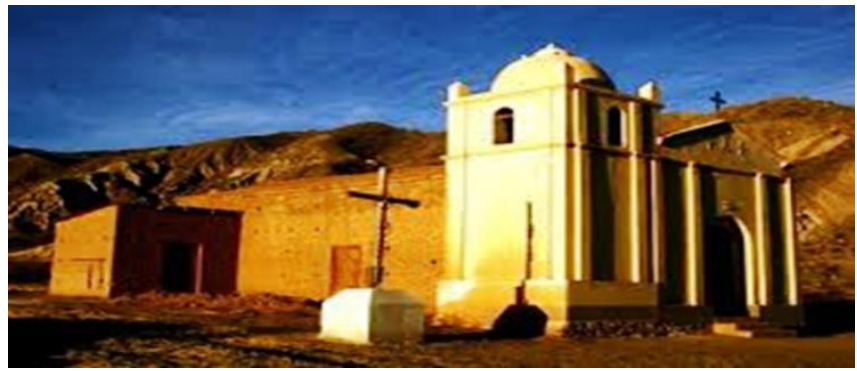

Fig. 5. The ancient church of Angastaco, Salta [6].

The conservation of ancient buildings takes on a new relevancy when it comes time to build a house or a home. Ideally a minimum 50 to 70 years useful lifetime can be expected [7], with a minimum amount of maintenance. Bui [8], in his study of unstabilized rammed earth walls, concluded that after 20 years of exposure to the elements the level of erosion corresponded to $1,6 \%$ of the thickness of the wall, which led to an extrapolated lifetime of over 60 years. The conservation of buildings is, in itself, a sustainable action and the development of compatible materials and reusage of old materials should become a growing concern [9]. But earth buildings are subject to much greater deterioration than masonry constructions. Several authors have addressed the issue of durability, among them Chiappero [10], who addressed the issue from the point of view of pathologies in earth architecture. He emphasized that the main causes of damage that affect the durability of earth constructions are humidity, wind, the presence of vegetable matter, attacks by animal and incorrect interventions. According to Graham [11] wattle and daub durability can frequently be improved by coating with plaster since it fills in any cracks and can be worked into the gaps which consistently appear around the panel edge due to shrinkage of the daub. HABITERRA [12] stated that the straw, the dung, the asphalt and other materials can be expertly added to the plastic earth mass to reduce shrinkage during drying, improve waterproofing or increase durability. In the case of adobe enclosures, PROTERRA [13] explains that superficial finishes in traditional constructions can be "cured" with milk or penca juice or lime milk and fat for waterproofing, the surface smoothed and contours rounded to channel rain water, allowing for greater durability and increased useful lifetime. Finally, in Pacheco [14] durability was assessed by accelerated aging tests. The main mechanism responsible for the erosion of earth walls had to do with the kinetic energy of the impact of rainfall. This explains the poor durability behavior of earth walls that are south-facing, a direction usually associated with wind based rain.

With a view to gathering information about the lifetime of earth construction in seismic zones, this paper analyzes the constructive characteristics, the constructive pathologies, the thermal behavior and the current condition of an Experimental Workshop (E.W.), constructed using wattle and daub techniques.

The E.W. was built at the beginning of 2004 by the engineer Alfredo Esteves, and the architect Esteban Fernández, and its purpose was to house experimental research relating to the development of solar devices, such as solar ovens, solar distillers, passive solar heating systems and windows systems, among others. The E.W. is located in the grounds of the INAHE - CONICET - Institute for the Environment, Habitat and Energy, in Mendoza province, in central-western Argentina.

Motivated by the need to find alternatives to palliate the rural housing deficit and given the growing interest in bio construction, it was built using reeds, mud, wood for the structure, etc., all of which are easy to obtain in the local rural environment. At the same time the aim was to showcase the building techniques involved in earth construction, transfer the know-how and teach the skills required by holding courses at the E.W. [15].

\section{DESCRIPTION OF THE EXPERIMENTAL WORKSHOP}

The E.W. consists of an area measuring $5.70 \mathrm{~m}$ wide and $5.90 \mathrm{~m}$ long. The interior is divided into two sections, one for manufacturing and assembling equipment and the other a depot for storing valuable materials, machinery and tools (see Fig. 6 and Fig. 7).

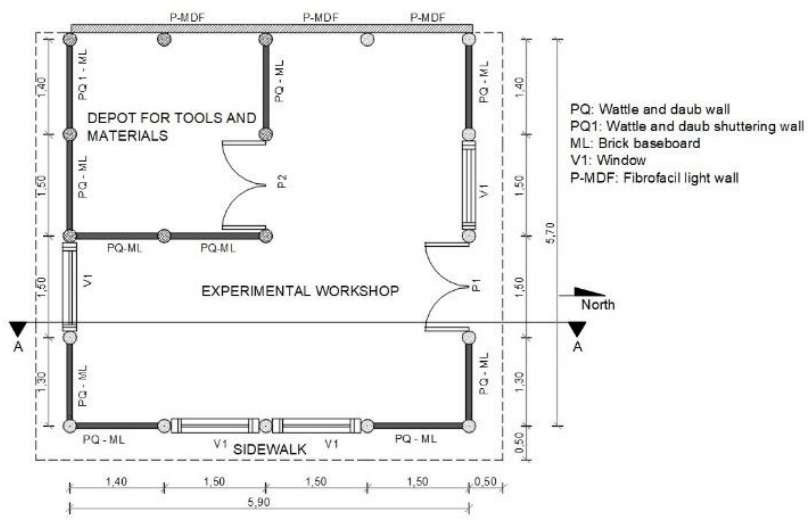

Fig. 6. Experimental Workshop floor plan.

The constructive technology and materials used are the following: a) structure, poplar wood (Populus nigra) columns and beams, with an average diameter of $0.20 \mathrm{~m}$ for columns and $0.16 \mathrm{~m}$ for beams. The columns have two edges that allow them to fit into the slats more easily. The beams are edged on one side to provide support for the ceiling. The lower part of the columns are painted with solvent-based asphalt paint and are supported diagonally by several ribbed steel braces, $0.008 \mathrm{~m}$ in diameter that extend $0.25 \mathrm{~m}$ on each side. Each one is anchored into a cyclopean concrete block $0.60 \mathrm{~m}$ wide $\mathrm{x} 0.60 \mathrm{~m}$ long $\mathrm{x} 0.70 \mathrm{~m}$ deep (Fig. 7). 


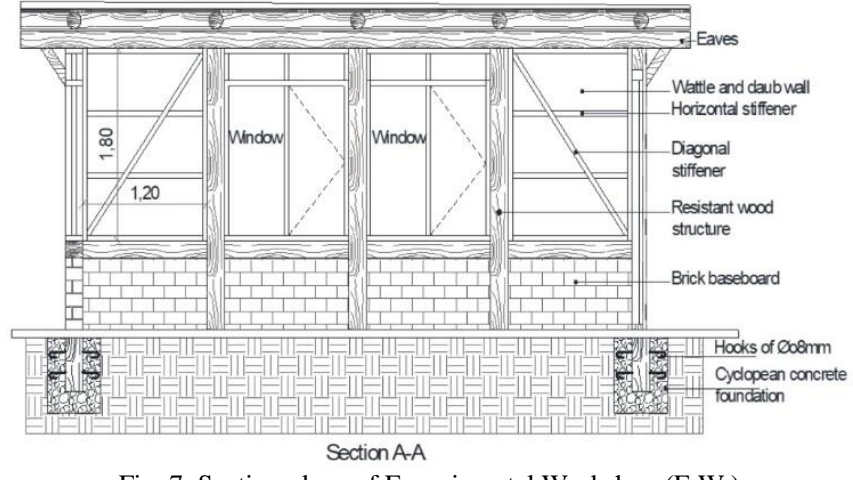

Fig. 7. Section plane of Experimental Workshop (E.W.)

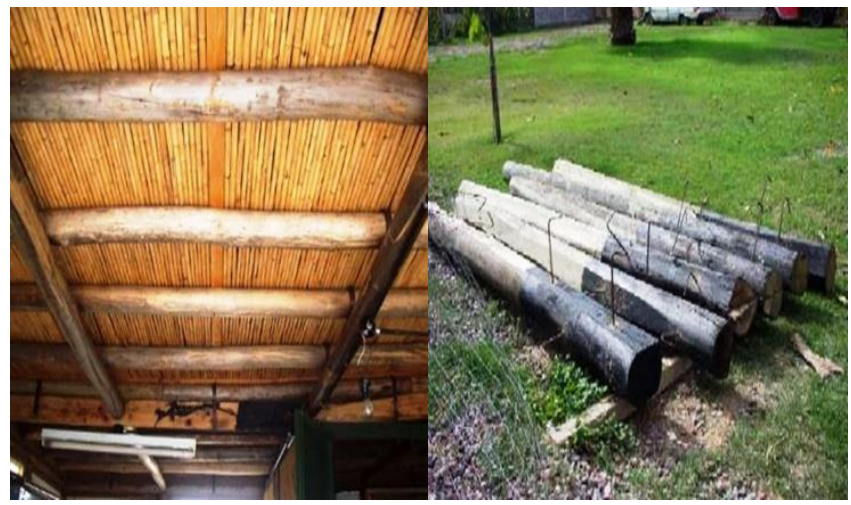

Fig. 8. a-Cane roof and b- Eucalyptus wood columns.

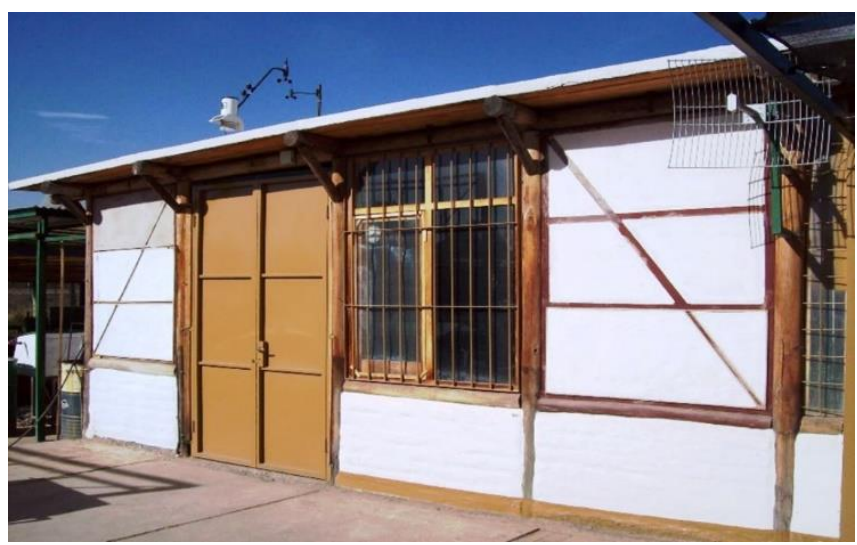

Fig. 9. Workshop with finished wattle and daub walls.

To avoid moisture ascending by capillarity from the soil into each wall, a small wall consisting of six rows of bricks laid with water-repellent concrete was assembled between the columns and poplar logs were placed on top (see Fig. 7 and Fig. 9).

The floor was made with reinforced concrete poured over a $4.2 \mathrm{~mm}$ ribbed steel mesh in $0.15 \mathrm{~m}$ squares.

The roof structure (Fig. 8), consists of poplar logs with a minimum incline. The ceiling was made of Castile cane Arundo donax and laid across the poplar logs along with the vapor barrier, 150-micron polyethylene sheeting, the thermal insulation of $1.5 \mathrm{~cm}$ of expanded polystyrene and 8 $\mathrm{cm}$ of volcanic granulate with concrete, and the waterproof insulation of a rubber membrane with embossed $4 \mathrm{~mm}$ thick aluminum.

Around the E. W's entire perimeter, the roof extends over the walls creating $40 \mathrm{~cm}$-wide eaves which provide the earth walls with protection from the rain. Window frames are made of poplar wood measuring $1.20 \mathrm{~m}$ in width and $1.80 \mathrm{~m}$ in height. One is located on the northern and one on the southern façade and two on the eastern façade to allow for sufficient daylight and crossed ventilation.

The width of the wattle and daub panel is equal to the distance between the structure's columns. For the infill for the framework Castile cane [15] was used (see Fig. 10) and was then covered with mud prepared with clay, horse dung and water, to a final thickness of $7.5 \mathrm{~cm}$. The PQ1 wattle and daub framework is devised by fastening the canes together leaving a space between them, which is then filled with a mixture of pomeca puzolánica and concrete, thus forming a thermally improved wattle and daub.

The walls consist of two different types of wattle and daub: PQ and PQ1 wattle and daub panels. The PQ type was used on the northern and eastern facades and on the inside walls and the PQ1 type was used on the southern facade. In both cases poplar wood was used for the frame, but the PQ type required diagonal braces and two horizontal reinforcements (see Fig. 10 and Fig. 11).

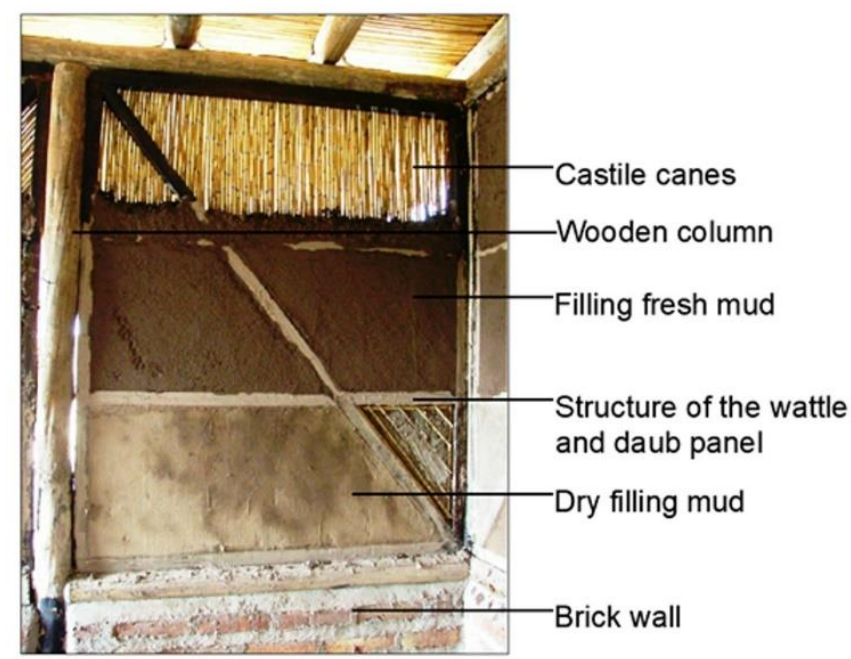

Fig. 10. Detail of wattle and daub wall infill techniques.

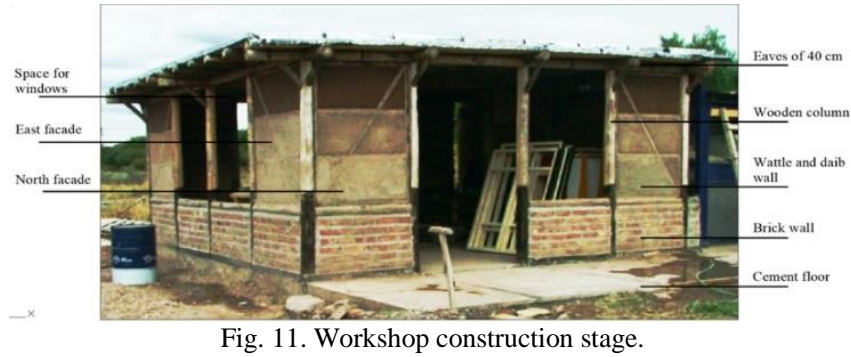

\section{PAThOlOGIES AND MAINTENANCE OF E.W}

In the years since its construction, the E.W. has been used for experimental research related activities, mainly workshop activities, such as welding, cutting pipes or wood, assembly of solar ovens, among others. It is exposed to a semiarid-arid climate and is located in an area of Category 3 high seismic hazard [16].

In order to preserve the constructive integrity of the E.W, throughout the years maintenance work was carried out on the opaque wattle and daub walls that had suffered damage, as shown in Fig. 12. The image on the left shows the front north-facing wattle and daub wall affected by moisture, and where some of the cane became exposed. One problem that arose after construction was that as the wooden supports for 
the north and south-facing eaves protrude a few centimeters from the eaves, (see Fig. 12b), on rainy days they caused seepage from the wooden support down to the columns, creating a partial deterioration of the wood and the wattle and daub walls. This problem was solved by plastering the wattle and daub walls on the north-facing façade with a lime mixture.

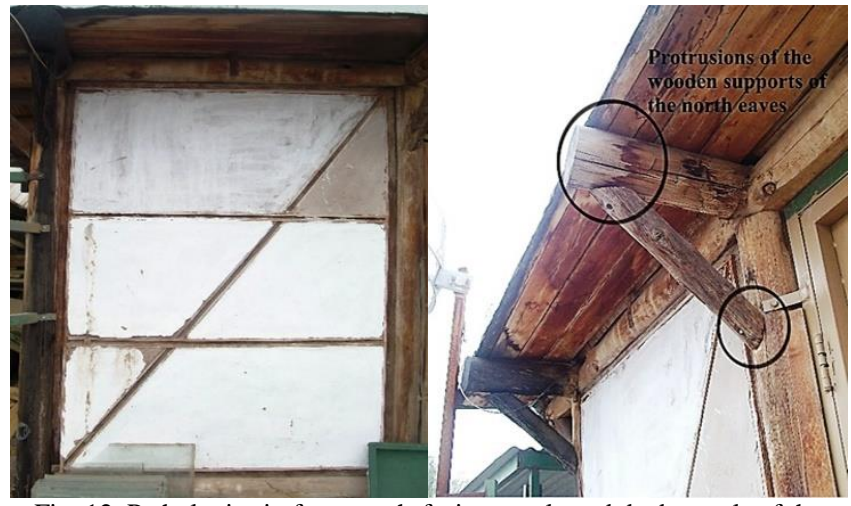

Fig. 12. Pathologies in front north-facing wattle and daub panels of the E.W.

Fig.13 shows the small amount of mud that came loose and minor cracks that formed in the thermally enhanced wattle and daub wall. On the south-facing wall a cement mixture was used for added protection, and was also used to render the entire brick wall. Despite the outside damage, the interior surface of the wall is in perfect condition, as shown by the fact that the cane has retained its natural color and has suffered no deterioration. However, it is necessary to keep up with maintenance and to repair the wooden eaves that show moisture damage. On the eastern facade, the ceiling has suffered no damage as it has been protected by a roof that was built on that side in 2008 .

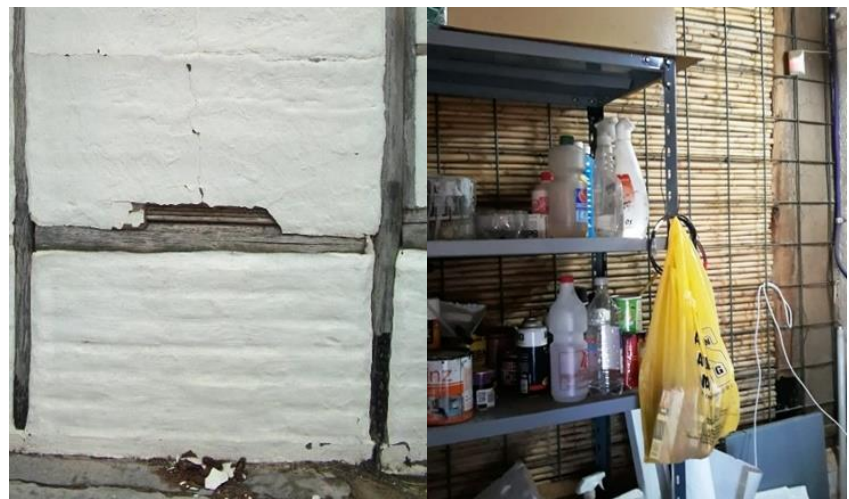

Fig. 13. Pathologies in south-facing wattle and daub panels, a-outside and b-inside surfaces.

The second pathology found was cracks of no more than $3 \mathrm{~mm}$ wide along some edges where the mud and the wooden frame join to form the wattle and daub wall (Fig. 14). In the interior no such cracks appeared. The solution was to seal the cracks with silicone sealant, which with its characteristic flexibility and durability is perfectly suited to the expansion and contraction of the materials used in wattle and daub walls.

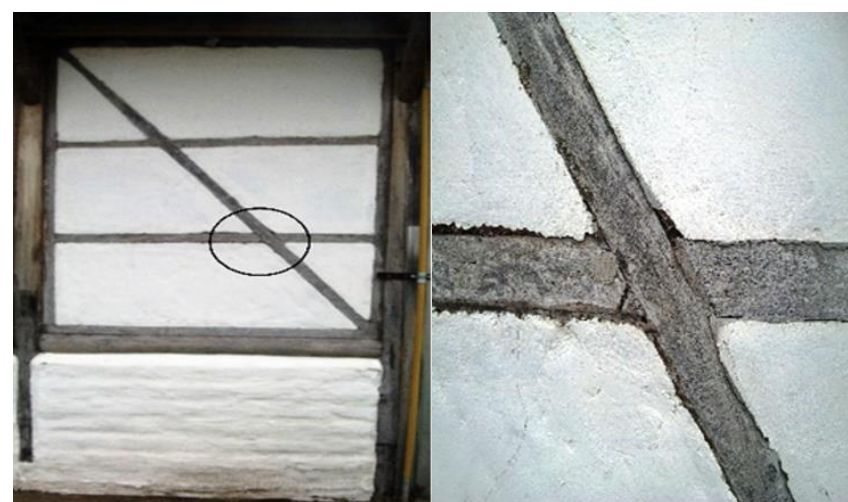

Fig. 14. Pathologies in joints on wattle and daub walls: a- Northern wall. bDetail exterior joint.

Although after 14 years of operation micro cracks have appeared in some sections of the walls of the E.W., (Fig. 15), these do not present any structural risks and can be easily sealed with a little mud or by repainting the walls.

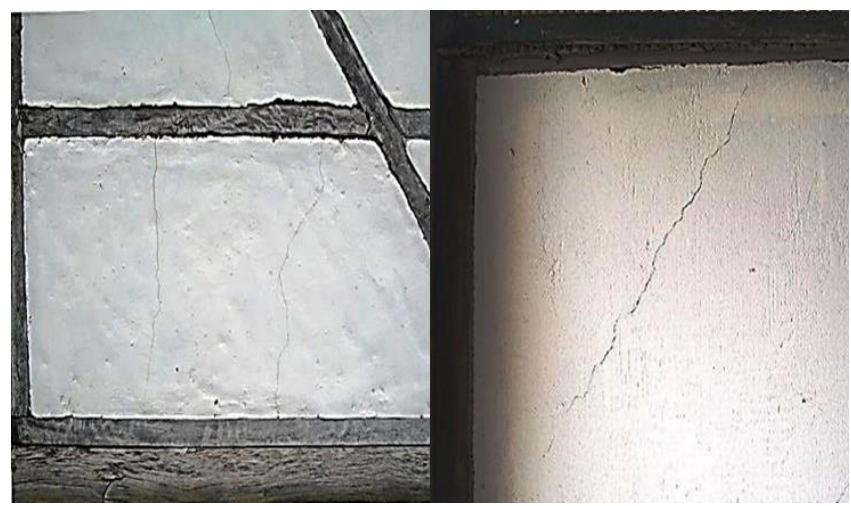

Fig. 15. Micro cracks on wattle and daub walls

It is important to note that few pathologies have been found in the E.W. building, and it has generally had a satisfactory response behavior, as shown in Fig. 16 and Fig. 17 , bearing in mind that it was not conceived as a typical family home and has been exposed to damage from workshop activities.

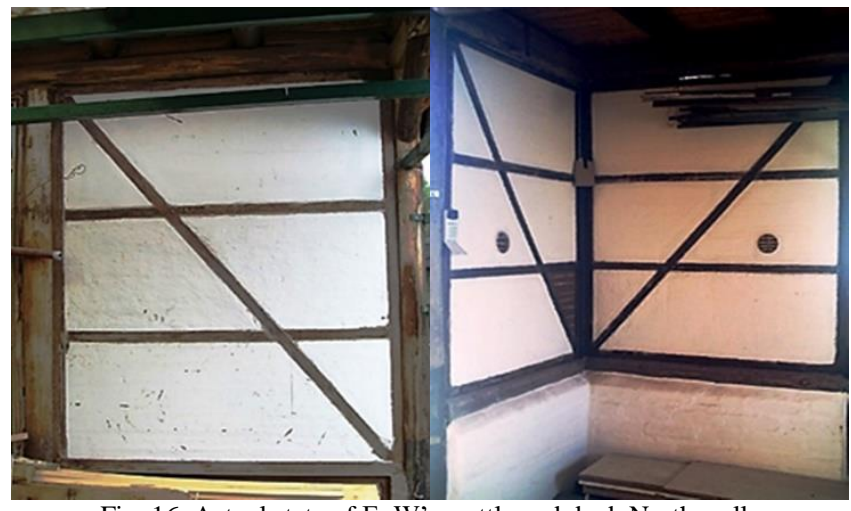

Fig. 16. Actual state of E. W's wattle and daub North walls 


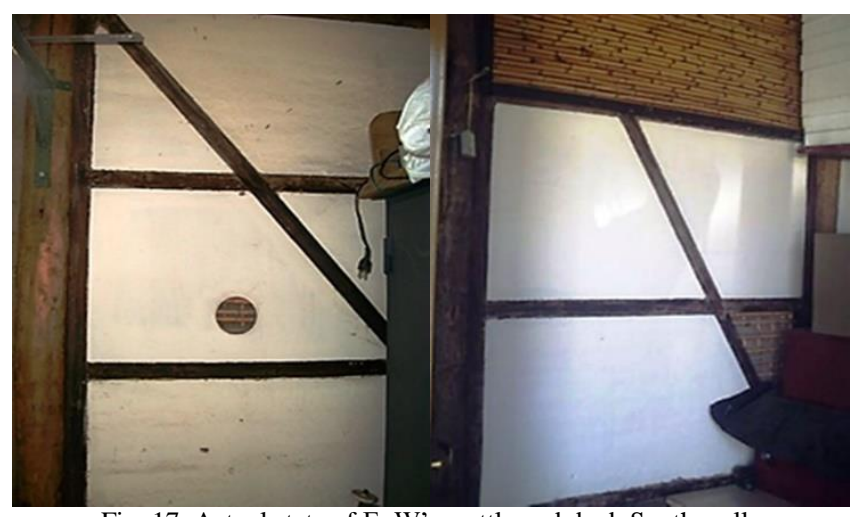

Fig. 17. Actual state of E. W's wattle and daub South walls

\section{THERMAL RESPONSE}

Despite the pathologies observed on the wattle and daub walls, the E.W retains an acceptable thermal response. The E. W's thermal response was analyzed in two phases: in the first, the thermal transmittance of a $0.075 \mathrm{~m}$ thick wattle and daub wall was theoretically analyzed, taking as a basis the transmittance calculation for each row of cane, with $\mathrm{R}=0,209 \mathrm{~m}^{2 \circ} \mathrm{C} / \mathrm{W}$ [17], giving a value of $2.32 \mathrm{~W} / \mathrm{m}^{2} \mathrm{~K}$ [18]. This value is comparable to that of a $0.20 \mathrm{~m}$ thick brick wall (cement-plastered on both sides) with a thermal transmittance of $2.4 \mathrm{~W} / \mathrm{m}^{2} \mathrm{~K}$. Furthermore, by transforming a wattle and daub north facing wall into a passive Trombe type wall without openings towards the interior and with a transparent polyethylene cover, an increase of $12^{\circ} \mathrm{C}$ in the interior surface temperature is achieved [19].

In the second phase, a data logger with temperature and relative humidity sensors was placed both outside and inside and registered temperature data every 15 minutes, while at the same time recording solar radiation and wind (direction and speed). The reading was taken between August $22^{\text {nd }}$ and August $28^{\text {th }}$ (winter in the southern hemisphere), see Fig. 18.

Thermal behavior can be divided into three phases:

- Phase 1: 3 consecutive sunny days

- $\quad$ Phase 2: 1 cloudy day and 1 partially cloudy day

- Phase 3: 2 consecutive sunny days

Phase 1: The graph clearly shows that the maximum temperatures on both curves are even due to air filtrations in the carpentry section of the workshop and the opening and closing of the entrance door during working hours, excluding weekends. During the early morning a difference in both temperatures is registered, and while outside the minimum is between $1^{\circ} \mathrm{C}$ to $3^{\circ} \mathrm{C}$, inside it is between 6 to $8,3^{\circ} \mathrm{C}$ for the first three days, making a difference of nearly $5^{\circ} \mathrm{C}$. Outside the thermal amplitude is between 16 to $18^{\circ} \mathrm{C}$, while inside it is between 9 to $11^{\circ} \mathrm{C}$.

Phase 2: On the cloudy day, the outside thermal amplitude is $7^{\circ} \mathrm{C}$, while inside it is $4^{\circ} \mathrm{C}$. It is interesting to note that as solar radiation peaks near midday, while the outside temperature increases the inside temperature does not, due to the thermal inertia of the building. On the partially cloudy day the outside thermal amplitude is $13^{\circ} \mathrm{C}$, while inside it is $8^{\circ} \mathrm{C}$.

Phase 3: two clear days with thermal behavior similar to Phase 1 , the outside thermal amplitude being $15-16^{\circ} \mathrm{C}$ while inside it is $10^{\circ} \mathrm{C}$.
All of the days registered show that the indoor temperature decreases much less than the outdoor temperature and this helps to rapidly increase indoor temperatures the next morning. It is important to point out that these measurements were made without auxiliary heating.

Furthermore, and in reference to the fact that measuring and recording the interior of the E.W. has been an ongoing process, in the paper presented in 2010 [20] about the hygrothermic behavior of wattle and daub constructions based on measurements taken at the E.W. in 2008, (see Fig. 19), it can be observed that the interior thermal amplitude for winter was $9^{\circ} \mathrm{C}$, compared to $12^{\circ} \mathrm{C}$ on average in the exterior: after fourteen years and several pathologies, the interior thermal amplitude is $9^{\circ} \mathrm{C}$ on average compared to $14^{\circ} \mathrm{C}$ in the exterior. This response shows the thermal reliability of wattle and daub and its durability over time, thus providing stable thermal behavior throughout the years.

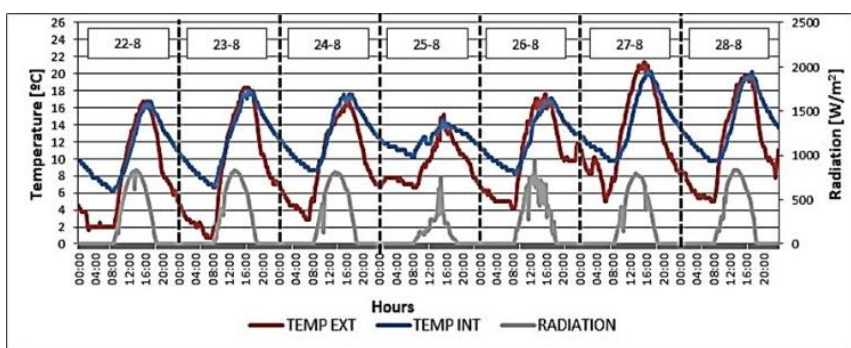

Fig. 18. Thermal behavior of the E.W

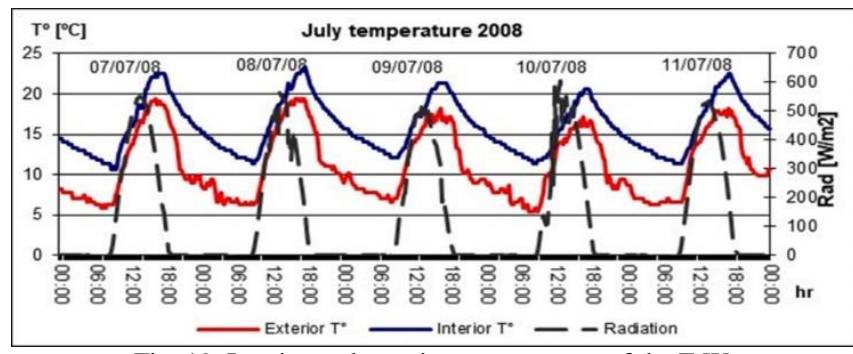

Fig. 19. Interior and exterior temperatures of the E.W.

\section{CONCLUSION}

After analyzing the pathologies of the wattle and daub construction, it was observed that with minimum maintenance the walls would last over time. However, without this maintenance, humidity could damage the surface of the wall and consequently moisture could penetrate the construction. For this reason, overhangs are so important in any earth construction, to provide protection for the walls and the wooden structure from the rain. Preventing degradation of its natural materials increases the lifetime of the construction.

In the case of the E.W, even though the walls were affected by humidity, because the problem was treated in time the building remains in good condition.

In addition, this study demonstrates that using wattle and daub techniques for building houses ensures that they will remain in perfect condition for at least 10 years with minimal maintenance. It also guarantees a good thermal response, allowing owners to experience near optimal thermal comfort levels with differences of approximately $6^{\circ} \mathrm{C}$ between the interior and the exterior on sunny days and without artificial heating. 
This study also highlights the fact that wattle and daub constructions are cheaper to build than brick constructions; they keep maintenance costs to a minimum and eliminate the need for skilled labor as they can be self-built. We aim to continue our research on wattle and daub in relation to structural behavior in older buildings over the course of time, in order to achieve safe, efficient and lasting constructions.

\section{REFERENCES}

[1] Vyncke1, J; Kupers, L and Denies N. (2018) Earth as Building Material - an overview of RILEM activities and recent Innovations in Geotechnics. MATEC Web of Conferences 149, 02001. https://doi.org/10.1051/matecconf/201814902001.

[2] Minke, Garnot. (2005). Manual de construcción para viviendas antisísmicas de tierra. Universidad de Kessel - Alemania.

[3] Ciancio, D; Beckett, C. (2015). Rammed Earth Construction: Cutting-Edge Research on Traditional and Modern Rammed Earth Ed. University of Western Australia. ISBN 978-1-138-02770-1.

[4] Bridgwood, B; Lennie, L. (2009). History, Performance and Conservation. Ed. Taylor \& Francis. Pp. 337. ISB:0-415-43419.

[5] Pierdicca, Roberto. (2018). Mapping Chimu's settlements for conservation purposes using UAV and close range photogrammetry. The virtual reconstruction of Palacio Tschudi, Chan Chan, Peru. Digital Applications in Archaeology and Cultural Heritage. Pp. 2734. Elsevier Ltd.

[6] Manitoba. (2010). Salta - Refugio del Tiempo. Gobernación de Salta. Manitoba, agencia de comunicación. Photography: Gustavo Guijarro. Ed. Cartoon S.A. Salta.

[7] Esteves A., De Rosa C. (1995). Duración de las reservas de combustibles fósiles y su relación con la vida útil de los edificios. Proceedings of XVIII Workshop de ASADES, Vol. III, pp. 09.9 09.14. Ciudad de San Luis. Argentina.

[8] Bui, Q.B; Morel, J.C; Venkatarama Reddy, B.V; Ghayad, W. (2009). Durability of rammed earth walls exposed for 20 years to natural weathering. Building and Environment, ISSN: 0360-1323, Vol: 44, Issue: 5, Page: 912-919.

[9] Costa C; Cerqueira Â; Rocha F and Velosa A. (2018). The sustainability of adobe construction: past to future. International Journal of Architectural Heritage. ISSN: 1558-3058 (Print) 15583066 (Online).

[10] Chiappero, Rubén y Supisiche, María. (2003). Arquitectura en tierra cruda. Ed. Nobuko. ISBN: 987-20641-5-6.

[11] Graham, T. (2003). Wattle and Daub: Craft, Conservation and Wiltshire Case Study. Pp. 111. Department of Architecture and Civil Engineering University of Bath.

[12] HABITERRA XIV. (2003). Arquitecturas de Tierra en Iberoamérica. Ed. Mendez, P. Centro Barro, Argentina.

[13] PROTERRA. (2003). Técnicas mixtas de construcción con tierra. HABYTED Subprograma XIV - Tecnología para Viviendas de Interés Social.

[14] Pacheco-Torgal, F; Said Jalali. (2012). Earth construction: Lessons from the past for future eco-efficient construction. Construction and Building Materials. Pp. 512-519.

[15] Fernández, J.E.; Esteves, A.; Oviedo, G.; Buenanueva, F. (2005). La quincha, una tecnología alternativa eficiente para la autoconstrucción. Aspectos educativos. Rev. AVERMA Vol. 9, Secc. 10, pp. 25-29. Salta, Argentina.

[16] INPRES (2000). Instituto Nacional de Prevención Sísmica. Proyecto de reglamento argentino para construcciones sismorresistentes INPRES-CIRSOC 103.

[17] Esteves A., Ganem C., Fernáncez J.E., Mitchel. J. (2003). Thermal Insulating Material for Low-Income Housing. PLEA2003. Santiago de Chile. Ed. En Cd. Art. 11.
[18] Fernández, J.E.; Esteves, A. (2004). Conservación de energía en sistemas autoconstruidos. El caso de la quincha mejorada. Rev. AVERMA Vol. 8, Secc. 5, pp. 121-125. Salta, Argentina.

[19] Mercado, M.V. y Esteves, A. (2006). "Muro solar pasivo en viviendas construidas con quincha". Rev. AVERMA Vol. 10, secc. 5, pp. 107-114. Salta, Argentina.

[20] Cuitiño, G.; Esteves, A.; Maldonado, G.; Rotondaro, R. (2010). Análisis y reflexiones sobre el comportamiento higrotérmico de construcciones con quincha. Estudio del caso de un taller experimental en Mendoza. Rev. ÁREA. Universidad de Buenos Aires.

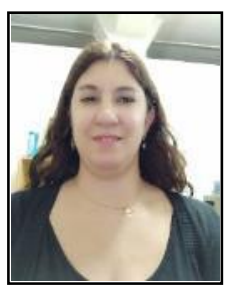

Guadalupe, Cuitiño is a Academician and Civil engineer, National Technological University (UTN), 2007. She was born in San Rafael, Mendoza, Argentina 09-03-1981. Her educational qualifications is $\mathrm{Ph} . \mathrm{D}$ in Exact Sciences with specialization in Renewable Energies, National University of Salta, Argentina, obtained in 2013 Currently, she is an Assistant Researcher of the National Scientifical and Technological Research Council (CONICET). He is also Head of Practical Works of Structures 1 in the Architecture career. Her research interests are: Bio-construction, earth construction, thermal behavior of the indoor environment, passive heating systems, thermal comfort. She belongs to several professional Association including Red Iberoamericana de Arquitectura y Construcción con Tierra ProTerra, also she belongs to National Council of Scientific and Technical Research. Same publications are: 1- G. Cuitiño, A. Esteves, G. Maldonado, R. Rotondaro. 2015. Análisis de la transmitancia térmica y resistencia al impacto de los muros de quincha. Informes de la Construcción. Vol. 67, 537, e063. enero-marzo 2015. ISSN-L: 0020-0883. doi: http://dx.doi.org/10.3989/ic.12.082. 2Cuitiño Guadalupe; Esteves Alfredo; Barea Gustavo; Marín Laura; Bertini Renato. (2018). Thermal Performance of "Quincha" Constructive Technology in a Mountainous Region. International Journal of Construction Engineering and Management. Pp: 53-64. DOI: 10.5923/j.ijcem.20180702.01.

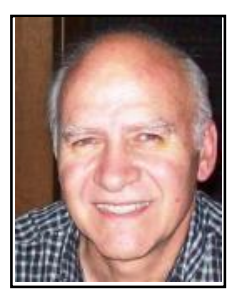

Alfredo Esteves Miramont. Born in Mendoza, Argentina 06-15-56. Industrial Engineer, National University of Cuyo (UNC), 1984. Dipl.: Designer in Solar Energy Systems. 1994. Solar Energy Study Center-Sevilla-España. $\mathrm{PhD}$ in Architecture, University of Mendoza, 2013. Fellow of the Science and Technical National Secretary (SECYT) of Argentina, International Centre of Theoretical Phisycs (ICTP) Trieste, Italy, Solar Energy Study Center-Sevilla-España.

$\mathrm{He}$ currently works as a researcher of National Scientifical and Technological Research Council (CONICET), from 1992 and full Professor of the Chair of "Technics and Procedures of Sustainable Design" in School of Architecture, University of Mendoza, from 1999. Assistant to 63 national and international workshop, conferences and Congress, in 42 as lecturer. Author or co-author of 112 papers and 8 in books in national or international reviews or congress proceedings. (See https://www.researchgate.net/profile/Alfredo_Esteves). Tutor of Scientifical Scholarship and Postgraduate thesis (12). Participated in 45 cases of technology transfer to the community, in buildings of bioclimatic schools (12), sustainable housing (18) and workshops to self-construction solar cookers in rural communities of Argentina (25).

Member of Argentine Association on Renewable Energy and Ambient from 1993, he was President from 2007 to 2011, Member of IASEE International Association for Solar Energy Education from 1994 to date Member of ISES International Solar Energy Society from 1995 to 2002 Member of Solar Box Cookers International, from 1999. 